\section{Mixed antigen ELISA of Mycoplasma pulmonis and $M$. arthritidis for diagnosis of murine mycoplasmosis}

\author{
ELISA com antígeno misto de Mycoplasma pulmonis e \\ M. arthritidis para diagnóstico da micoplasmose murina
}

\begin{abstract}
Mariana Thomaz de Oliveira e Silva"*, Maria Lúcia Barreto², Jenif Braga de Souza,4, Elmiro Rosendo do Nascimento ${ }^{5}$, Maurício Afonso Verícimo ${ }^{6}$ \& Veronica Figueiredo do Amaral ${ }^{6}$

'Biologist, MSc. Núcleo de Animais de Laboratório, Pró-Reitoria de Pesquisa, Pós-graduação e Inovação - Proppi, Universidade Federal Fluminense - UFF, Niterói, RJ, Brasil

${ }^{2}$ Veterinary, PhD. Núcleo de Animais de Laboratório, Pró-Reitoria de Pesquisa, Pós-graduação e Inovação - Proppi, Universidade Federal Fluminense - UFF, Niterói, RJ, Brasil

${ }^{3}$ Veterinary, MSc. Faculdade de Ciências Médicas, Universidade do Estado do Rio de Janeiro - UERJ, Rio de Janeiro, RJ, Brasil

${ }^{4}$ Veterinary, MSc. Instituito de Ciências em Biomodelos, Fundação Oswaldo Cruz - Fiocruz, Rio de Janeiro, RJ, Brasil

${ }^{5}$ Veterinary, PhD. Faculdade de Medicina Veterinária, Universidade Federal Fluminense - UFF, Niterói, RJ, Brasil

${ }^{6}$ Veterinary, PhD. Departamento de Imunobiologia - DI, Instituto de Biologia - IB, Universidade Federal Fluminense - UFF, Niterói, RJ, Brasil
\end{abstract}

\begin{abstract}
Infection of rodent colonies with microorganisms of the genus Mycoplasma may interfere with the results of scientific research. Mycoplasma pulmonis and Mycoplasma artbritidis are the main agents of this genus, and their prevalence can reach $100 \%$ in conventional vivariums in developing countries. The detection methods available on the market usually have limitations. One of the most frequently used tests is the enzyme-linked immunosorbent assay (ELISA), which has high sensitivity and specificity and low cost. This work aimed to develop a mixed antigen ELISA test of M. pulmonis and M. artbritidis and evaluate its performance as an alternative diagnostic method for mycoplasmosis. Sera from 81 mice were tested with M. pulmonis antigen (ELISA-Mp), M. arthritidis (ELISA-Ma), and 1:1 mixed antigen (ELISA-mix): $50.61 \%$ of the sera showed positive findings in ELISA-Mp, 44.44\% in ELISA-Ma, and 46.91\% in ELISA-mix. The ELISA-mix had a sensitivity of $72.00 \%$, specificity of $64.28 \%$, and a positive predictive value of $47.36 \%$. Statistical analysis of the data showed agreement between the ELISA-Mp and the ELISA-mix. The mixed ELISA test developed shows satisfactory sensitivity and specificity and may contribute significantly to the improvement of sanitary standards in laboratory animal facilities and to the development of experimental research.
\end{abstract}

Keywords: ELISA, diagnosis, murine mycoplasmosis.

\section{Resumo}

A infecção de colônias de roedores por microrganismos do gênero Mycoplasma pode causar interferências no resultado de pesquisas científicas. Mycoplasma pulmonis e Mycoplasma artbritidis são os principais agentes deste gênero, e sua prevalência pode chegar a 100\% em biotérios convencionais nos países em desenvolvimento. A detecção pelos métodos disponíveis no mercado normalmente apresenta limitações. Um dos testes mais utilizados é o ELISA, com elevada sensibilidade, especificidade e baixo custo. Este trabalho teve como objetivo desenvolver um teste de ELISA com antígeno misto de M. pulmonis e M. arthritidis e avaliar o seu desempenho como método alternativo de diagnóstico de micoplasmose. Soros de 81 ratos foram testados utilizando antígeno de M. pulmonis (ELISA-Mp), M. arthritidis (ELISA-Ma) e antígeno misto a 1:1 (ELISA-mix). 50,61\% dos soros foram positivos no ELISA-Mp, 44,44\% no ELISA-Ma e 46,91\% no ELISA-mix. No ELISA-mix houve sensibilidade de 72,00\%, especificidade de 64,28\% e valor preditivo positivo de 47,36\%. A análise estatística dos dados mostra concordância entre o ELISA-Mp e o ELISA-mix. O teste de ELISA misto desenvolvido apresenta padrão de sensibilidade e especificidade satisfatório, e pode contribuir de forma expressiva para a melhora do padrão sanitário dos animais de laboratório e para o desenvolvimento de pesquisa experimental.

Palavras-chave: ELISA, diagnóstico, micoplasmose murina.
How to cite: Silva, M. T. O., Barreto M. L., Souza, J. B., Nascimento, E. R., Verícimo, M. A. \& Amaral V. F. (2018). Mixed antigen ELISA of Mycoplasma pulmonis and $M$. arthritidis for diagnosis of murine mycoplasmosis. Brazilian Journal of Veterinary Medicine, 40, e96218. doi: 10.29374/2527-2179. bjvm096218

Financial support: Coordenação de Aperfeiçoamento de Pessoal de Nível Superior (CAPES), Conselho Nacional de Desenvolvimento Científico e Tecnológico (CNPq), Fundação Carlos Chagas Filho de Amparo à Pesquisa do Estado do Rio de Janeiro (FAPERJ) and the Programa de Fomento à Pesquisa (FOPESQ) - UFF.

Conflict of interests: No conflict of interests declared concerning the publication of this article.

Received: June 26, 2018

Accepted: September 01, 2018.

The study was carried out at Núcleo de Animais de Laboratório, Universidade Federal Fluminense, - UFF, Niterói, RJ, Brasil.

\section{*Correspondence}

Mariana Thomaz de Oliveira e Silva

Núcleo de Animais de Laboratório,

Pró-Reitoria de Pesquisa, Pós-Graduação

e Inovação (Proppi), Universidade Federal Fluminense - UFF,

Rua Miguel de Frias, 9, 30 Andar, Campus Valonguinho, Icaraí

CEP 24220-900 - Niterói (RJ), Brasil

E-mail:mariana_tos@yahoo.com.br

Copyright Silva et al. This is an Open Access article distributed under the terms of the Creative Commons Attribution Non-Commercial License which permits unrestricted non-commercial use, distribution, and reproduction in any medium provided the original work is properly cited. 


\section{Introduction}

Rats and mice are the most commonly used animals in research, and their sanitation and genetic standardization are important for development of models for understanding various biological mechanisms. Infections by pathogens may affect the validity of the investigated data and lead to erroneous interpretations or conclusions of experimental data (Schoondermark-Van de Ven et al., 2006). Subclinical infections are the most worrying because they remain unnoticed in the breeding and experimentation areas (Mähler Convenor et al., 2014). Pathogenic microorganisms may also persist in biological materials such as cell cultures and tumors for unlimited periods and thereby influence in vitro experiments (GV-SOLAS Working Group on Hygiene, 1999).

Thus, maintaining sanitation levels in these animals is key to obtain reliable results. Periodic sanitary monitoring of breeding and experimentation colonies is an important tool in this respect.

A major challenge in animal experimentation around the world is to obtain animals free of bacteria of the genus Mycoplasma spp., a microorganism known for the absence of a cell wall. Mycoplasma pulmonis is the etiologic agent of murine respiratory mycoplasmosis (MRM). In its chronic form, the disease represents an important sanitation problem found in rats and mice, since these animals are now being used in scientific experiments (Dobbs et al., 2009).

Mycoplasma arthritidis is the second most important species for rodents because it is the etiological agent of arthritis or polyarthritis in rats and mice, and is known for possessing the MAM superantigen (Luo et al., 2008). This species can coexist with M. pulmonis (Kohn \& Barthold, 1984). There is evidence that subclinical mycoplasma infections are more common in vivariums (Davidson et al., 1994).

Mycoplasmas possess antigenic modulation mechanisms that can modify the immune system of the host (Nicolet, 1996), causing changes in the response profile to immunizations, medications, therapies, and induction of experimental pathologies. Furthermore, they are the most common sources of infection of cell cultures, with rates of infection varying between 15\% and 35\% (Drexler \& Uphoff, 2002). The origins of this contamination are the components of the culture medium and the cells obtained from infected animals (Razin, 1996; Mähler Convenor et al., 2014).

Respiratory infection and disease are common in conventional vivariums. The occurrence of murine mycoplasmosis varies between 75\% and 100\% (Manjunath et al., 2015; Souza et al., 2016) in developing countries, because of inadequate infrastructure and the lack of consistent health monitoring programs (Souza et al., 2016).

The infection rate in specific pathogen free (SPF) animal vivariums kept under sanitary barriers ranges between 3.2\% and 20\% (Mähler \& Köhl, 2009). Although the occurrence of mycoplasmas has decreased in recent years (Barreto et al, 2003; Mähler \& Köhl, 2009), periodic monitoring is still recommended, because in spite of the use of bio-exclusion barriers and assisted reproduction techniques, infections by this agent persist (Schoondermark-Van de Ven et al., 2006). Elimination in vivariums where rodents exhibit clinical and subclinical infections is difficult; thus, the use of prophylactic techniques for their control is more efficient (Amstislavsky et al., 2013).

The diagnosis of mycoplasmosis in rodents is based on the animal's sanitary standard and the methodology used in the monitoring program, which may include several methods to improve the accuracy of the results (Mähler Convenor et al., 2014). Culture-based methods for antigen detection are laborious because they involve sampling from several sites of the same animal; these methods are also time-consuming because they require highly specific and expensive techniques and may yield false-negative results (Davidson et al., 1994). On the other hand, although the polymerase chain reaction (PCR) technique is more sensitive, it is also subject to false-positive and false-negative results, compromising the diagnosis when used alone (Drexler \& Uphoff, 2002). In contrast, histopathological assessments only provide presumptive diagnoses that need to be validated by other methods (Barreto et al., 2003).

Since its development, the enzyme-linked immunosorbent assay (ELISA) has become the most widely used and recommended method for monitoring colonies, because of its advantages over other tests with respect to sensitivity, specificity, speed, simplicity, and cost. Therefore, its use is recommended in routine monitoring of colonies (Delgado \& Timenetsky, 2001; Schoondermark-Van de Ven et al., 2006; Mähler Convenor et al., 2014) and prevalence studies (Manjunath et al., 2015). Developed by sampling, it facilitates the screening of colonies, allowing the detection of positive sera using small amounts of blood without the need to euthanize the animals. 
In Brazil, the ELISA test for M. pulmonis was developed by Campos et al. (2000) and has since been used in different studies (Barreto et al., 2002). However, two separate tests are required for diagnosis of infections caused by M. pulmonis and M. arthritidis.

Since M. pulmonis and M. arthritidis have many antigens in common (Horowitz \& Cassell, 1978), their cross-reaction could be used in favor of the test, and a mixed antigen ELISA test should be efficient in detecting antibodies to both species. Thus, the mixed ELISA could become a valuable tool for rapid monitoring of infections by these highly prevalent mycoplasma species in rodent colonies. This work aimed to develop an indirect ELISA test with the antigens of M. pulmonis and $M$. arthritidis and evaluate its performance as an alternative method for diagnosis of MRM.

\section{Material and methods}

\section{Serum samples}

Serum samples were obtained from 81 rats (Rattus norvegicus) aged between 3 and 12 months from different breeding lines and different vivariums with distinct sanitary standards that were used by teaching and research institutions in the municipalities of Rio de Janeiro and Niterói.

The experiments were performed according to a protocol approved by the Ethics Committee for the Use of Laboratory Animals of the Fluminense Federal University (CEUA/UFF), under number 549.

\section{Antigen preparation}

The conditions for the antigen concentration test were established in serial dilution serum (base 3; 1:10000 conjugate). Standard strains of M. pulmonis (ATCC 19612) and M. arthritidis (GM360 PG6) were cultured in Mycoplasma A medium (Difco) and incubated at $37^{\circ} \mathrm{C}$ for 48 hours. The log stage and large-scale growth ( $>10^{9} \mathrm{UFC}$ in solid media) cultures were centrifuged at 5,O00G for 1 hour. The obtained pellet was washed three times in phosphate-buffered saline (PBS) pH 7.2 and re-suspended in the same PBS to yield a final volume of $3.0 \mathrm{~mL}$ per liter of culture. Protein concentration was determined by the modified Lowry method using bovine albumin $(1 \mathrm{mg} / \mathrm{mL})$ as standard.

\section{Standardization of the test}

In order to establish parameters for comparison with the mixed ELISA, ELISA standardization tests were performed for M. pulmonis and M. arthritidis, according to the methodology described by Campos et al. (2000); 96-well flat bottom microtiter plates, $300 \mu \mathrm{L} /$ well, were used.

\section{Determination of the ideal antigen concentration: sensitization of the solid phase (plaque)}

For determination of the ideal antigen concentration, three plaques were sensitized with M. pulmonis or M. arthritidis antigen at different concentrations: 2,4 , and $8 \mu \mathrm{g} / \mathrm{mL}$. The antigen suspension was diluted in 0.1 M carbonate-bicarbonate buffer, $\mathrm{pH}$ 9.6, for plate sensitization. Sensitization of the plaques with the mixed antigen was performed by addition of $M$. pulmonis and $M$. arthritidis antibodies at specific concentrations $(2,4$, and $8 \mu \mathrm{g} / \mathrm{ml})$ to a single volume of buffer, tested in different proportions: $70 \%$ M. pulmonis $+30 \%$ M. arthritidis, 50\% M. pulmonis + 50\% M. arthritidis, and 30\% M. pulmonis $+70 \%$ M. arthritidis.

\section{Determination of the optimal conjugate dilution}

Peroxidase-conjugated (Sigma Chemical Co. St Louis, MO) goat IgG and mouse anti-IgG were used to perform the tests. For determination of the optimal dilution of the conjugate, 1:10000 and 1:15000 dilutions were tested, as described by Campos et al. (2000).

\section{Determination of optimal serum dilution}

To determine the optimal serum dilution, tests were carried out with positive serum for M. pulmonis and M. arthritidis, which was obtained by bleeding rats who were previously inoculated with these microorganisms. Negative sera were obtained by bleeding SPF mice. 
The sera were distributed in base 2 serial dilution (ranging from 1/100 to 1/3200) and base 3 (from 1/100 to 1/24300) in plates sensitized with the above described antigen concentrations. Both sera were used as controls in the mixed plate.

\section{Execution of the test}

The plates were sensitized with $50 \mu \mathrm{L}$ of $M$. pulmonis antigen (ELISA-Mp), $M$. arthritidis (ELISA-Ma), and mixed (ELISA-mix) as described above, incubated overnight at $4{ }^{\circ} \mathrm{C}$, washed three times with sterile PBS pH 7.2 containing 0.05\% Tween 20 (PBS-Tween), dried, and used immediately. The test sera were diluted in PBS pH 7.2 and added to the plates with the samples distributed in triplicate and incubated at $37^{\circ} \mathrm{C}$ for two hours. After incubation, the plates were washed with PBS-Tween three times, and each well received $50 \mu \mathrm{L}$ of conjugate diluted in PBS and incubated in an oven at $37^{\circ} \mathrm{C}$ for one hour. After incubation, the plates were washed again and developed with orthophenylenediamine solution (OPD) (Sigma Aldrich ${ }^{\circledR}$ ) prepared just prior to use and kept at room temperature for 30 minutes. After this period, the reaction was interrupted with $50 \mu \mathrm{L}$ of $3 \mathrm{~N}$ sulfuric acid.

\section{Plate reading}

The optical densities (ODs) were determined with an ELISA reader (DNM-9602; Beijing Perlong New Technologies Ltd., China) at $450 \mathrm{~nm}$ wavelength. In all tests, antigen, conjugate, and substrate controls were included, and all values were obtained in triplicate.

\section{Cut-off point}

The methodology proposed by Santurio et al. (2006) was used with modifications to determine the cut-off point. The mean of the negative sera was chosen to define the cut-off point.

\section{Assessment of the sensitivity, specificity, Positive Predictive Value (PPV), and Negative Predictive Value (NPV) in mixed ELISA}

The mixed test was assessed for sensitivity (total number of patients considered positive) and specificity (total number of healthy patients considered negative), considering the results obtained in the isolation and/or PCR of samples collected from the animals that provided the sera for this study (typified as M. pulmonis) as indicative of disease.

\section{Statistical analysis}

Statistical analysis of the sensitivity and specificity and evaluations of the discrepancy between the findings from isolation/PCR assays and the ELISAs and the agreement between the specific and mixed ELISAs were performed. Different statistical methods were used for each of the steps: the analysis of variance (ANOVA) method was used to analyze the results of the standardization, sensitivity, and specificity evaluations of the specific and mixed tests; the binomial test of two proportions and the Fisher exact test were used for comparisons between ELISA and isolation/PCR detection; and the Kappa test was used for comparisons between specific and mixed ELISAs. The statistical analysis was performed at a 95\% confidence interval $(\mathrm{p}<0.05)$. The analyses were carried out using the program BioEstat 5.0 (Ayres et al., 2007).

\section{Results}

A significant increase was observed in the optical density (OD) of the positive serum with increments in the antigen concentration used $(0.455,0.761$, and 0.911 at concentrations of 2,4 , and $8 \mu \mathrm{g} / \mathrm{mL}$, respectively). In the test for the $M$. pulmonis antigen, the significant difference was observed only between concentrations of 2 and $8 \mu \mathrm{g} / \mathrm{mL}(\mathrm{P}<0.05)$, which was not the case for the $M$. arthritidis antigen. The values for serum positivity at concentrations of 4 and $8 \mu \mathrm{g} / \mathrm{mL}$ of the M. pulmonis and M. arthritidis antigens were very high (Figure 1). Thus, the lowest tested concentration ( $2 \mu \mathrm{g} / \mathrm{mL}$ ) was chosen, allowing the use of less antigen.

The antigen mixture of $M$. pulmonis and $M$. arthritidis (mixed plaque) was tested with different ratios (70\%/30\%, 50\%/50\%, and 30\%/70\%, respectively) under the same conditions for each specific test. At the 1/300 dilution, M. pulmonis-positive serum showed increasing absorbance 


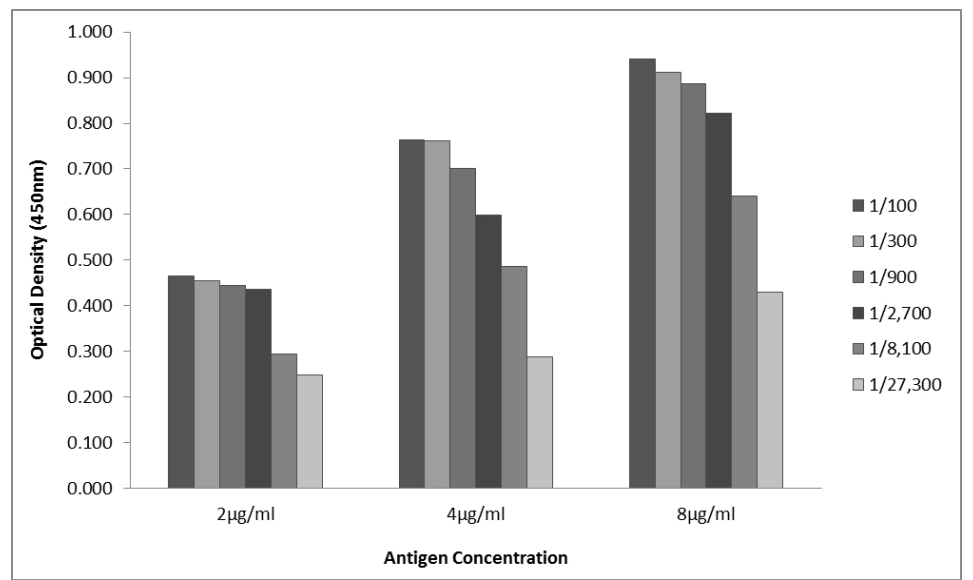

Figure 1. Comparison between the optical densities found in the ELISA test for M. pulmonis at concentrations of $2 \mu \mathrm{g} / \mathrm{mL}, 4 \mu \mathrm{g} / \mathrm{mL}$, and $8 \mu \mathrm{g} / \mathrm{mL}$.

values with an increase in the antigen ratio $(0.330,0.319$, and 0.302 for proportions of $70 \%, 50 \%$, and 30\% of M. pulmonis antigen, respectively), but no statistically significant differences were observed between the values. On the other hand, the $M$. arthritidis-positive serum at 1/300 dilution exhibited higher absorbance values for the three proportions. Significant differences ( $\mathrm{P}<0.05$ ) were observed between the $30 \%$ M. arthritidis antigen/70\% M. pulmonis antigen mixture relative to the mixture containing $50 \%$ of the both antigens $(0.639,0.575$, and 0.497 for M. arthritidis antigen proportions of 70\%, 50\%, and 30\%, respectively). In contrast, no significant difference was observed between 30\% M. pulmonis antigen/70\% M. arthritidis antigen relative to the mixture containing $50 \%$ of both antigens (Figure 2).

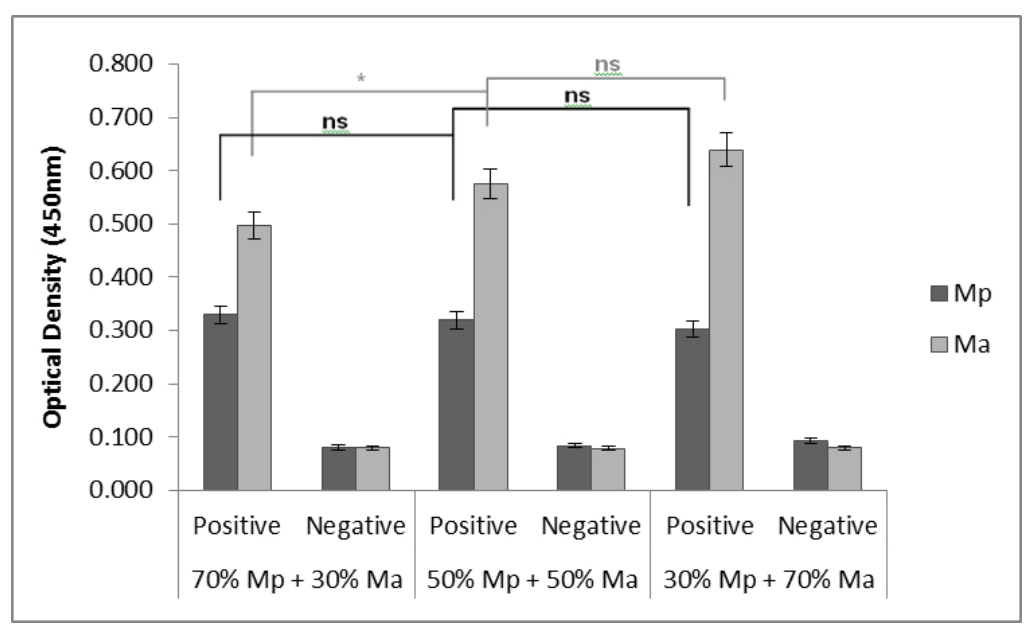

Figure 2. Comparison between the optical densities found in the anti-M. pulmonis and anti-M. arthritidis sera at $1 / 300$ dilution, when tested in mixed plates sensitized with $2 \mu \mathrm{g} / \mathrm{mL}$ antigen of $M$. pulmonis and $M$. arthritidis in different proportions. Statistical analysis using ANOVA; the significance levels between groups are represented as: $\left(^{*}\right)$ for significant $(\mathrm{P}<0.05)$ and $(\mathrm{ns})$ for non-significant $(\mathrm{P}>0.05)$.

Dilution of the sera in base 3 (Table 1) showed a gradual decrease in the OD values of the positive serum and retained the basal values in the negative serum more precisely than in base 2 , for both the specific and the mixed ELISAs (Table 2). Base 3 was selected to obtain the optimum serum dilution and the 1/300 dilution was chosen to perform the test because it showed good discrimination between the positive and negative controls and allowed detection of small amounts of antibodies in the samples. In determining the optimum dilution of the conjugate for the test, the best discrimination of values was obtained at the 1:10000 dilution in the three tests. 
Table 1. Optical densities (ODs) obtained for dilution of sera in base 3 for ELISA-Mp, ELISA-Ma, and ELISA-Mix.

\begin{tabular}{|c|c|c|c|c|c|c|c|}
\hline \multirow{2}{*}{\multicolumn{2}{|c|}{ Type of ELISA }} & \multicolumn{6}{|c|}{ Serum Dilution } \\
\hline & & $1 / 100$ & $1 / 300$ & $1 / 900$ & $1 / 2700$ & $1 / 8100$ & $1 / 24300$ \\
\hline \multicolumn{2}{|c|}{ M. pulmonis } & 0.506 & 0.497 & 0.491 & 0.354 & 0.245 & 0.167 \\
\hline \multicolumn{2}{|c|}{ M. arthritidis } & 0.613 & 0.584 & 0.573 & 0.549 & 0.479 & 0.376 \\
\hline \multirow{2}{*}{ Mixed } & M. pulmonis & 0.517 & 0.495 & 0.438 & 0.322 & 0.260 & 0.180 \\
\hline & M. arthritidis & 0.574 & 0.530 & 0.516 & 0.505 & 0.443 & 0.347 \\
\hline
\end{tabular}

Table 2. Optical densities (ODs) obtained in the dilution of the sera in base 2 for ELISA-Mp, ELISA-Ma, and ELISA-Mix.

\begin{tabular}{|c|c|c|c|c|c|c|c|}
\hline \multirow{2}{*}{\multicolumn{2}{|c|}{ Type of ELISA }} & \multicolumn{6}{|c|}{ Serum Dilution } \\
\hline & & $1 / 100$ & $1 / 200$ & $1 / 400$ & $1 / 800$ & $1 / 1600$ & $1 / 3200$ \\
\hline \multicolumn{2}{|c|}{ M. pulmonis } & 0.520 & 0.492 & 0.469 & 0.423 & 0.368 & 0.351 \\
\hline \multicolumn{2}{|c|}{ M. artbritidis } & 0.622 & 0.592 & 0.578 & 0.555 & 0.546 & 0.525 \\
\hline \multirow{2}{*}{ Mixed } & M. pulmonis & 0.422 & 0.411 & 0.366 & 0.341 & 0.309 & 0.286 \\
\hline & M. arthritidis & 0.549 & 0.521 & 0.487 & 0.471 & 0.461 & 0.442 \\
\hline
\end{tabular}

Comparison of the methods used for the cut-off point determination shows that the mean values of the negative sera yielded cut-off values of 0.151 for the ELISA-Mp, 0.149 for the ELISA-Ma, and 0.157 for the ELISA-mix, with a greater number of positive samples, consistent with the results obtained in the detection of mycoplasma by isolation and/or PCR while showing greater sensitivity than the other methods. From this point, 50.61\% (41/81) of the tested sera were positive in the ELISA-Mp (Table 3), 44.44\% (36/81) in the ELISA- Ma, and 46.91\% (38/81) in the ELISA-mix (Table 4).

Table 3. Crossing of results between isolation/PCR and ELISA-Mp detection.

\begin{tabular}{ccc}
\hline Test & ELISA-Mp $^{+}$ & ELISA-Mp - \\
\hline Isol/PCR + & 17 & 8 \\
Isol/PCR - & 24 & 32 \\
\hline
\end{tabular}

Table 4. Crossing of results between isolation/PCR and ELISA-Mix detection.

\begin{tabular}{ccc}
\hline Test & ELISA-Mix ${ }^{+}$ & ELISA-Mix - \\
\hline Isol/PCR + & 18 & 7 \\
Isol/PCR - & 20 & 36 \\
\hline
\end{tabular}

In assessments of the parameters to establish the validity of the methods used in this study (sensitivity, specificity, PPV, and NPV), the ELISA-Mp showed a sensitivity of 68.00\% and specificity of $57.14 \%$, with a PPV of $41.46 \%$ and NPV of $80.00 \%$. The ELISA-mix showed a sensitivity of $72.00 \%$ and specificity of $64.28 \%$, with a PPV of $47.36 \%$ and NPV of $83.72 \%$, indicating that the ELISA-mix has greater ability to detect positive and negative sera relative to the specific method (Table 5).

The differences between the ELISAs and the isolation/PCR were compared using the two-way binomial test, showing significant differences in both the isolation/PCR and ELISA-Mp comparison and between the isolation/PCR and ELISA-mixed comparison ( $p<0.05)$. Similarly, the results of 
Table 5. Sensitivity, specificity, positive predictive value (PPV), and negative predictive value (NPV) observed in the ELISA-Mp and ELISA-Mix tests.

\begin{tabular}{ccccc}
\hline Test & Sensitivity \% & Specificity \% & PPV \% & NPV \% \\
\hline ELISA-Mp & 68.00 & 57.14 & 41.46 & 80.00 \\
ELISA-Mix & 72.00 & 64.28 & 47.36 & 83.72 \\
\hline
\end{tabular}

both tests were significant when analyzed by Fisher's Exact test $(\mathrm{p}<0.05)$. The Kappa correlation analysis was also used for comparison of the results obtained with ELISA-Mp and ELISA-mix, showing an agreement of 83.95\% ( $\mathrm{p}<0.0001)$.

\section{Discussion and conclusions}

In Brazil, the use of laboratory animals with defined sanitary quality is very restricted. Most of the animals meet the conventional standards, encouraging the presence of pathogenic microorganisms that can result in clinical and subclinical infections and thus cause a drop in production, high mortality, and interference in the experimental results (Barreto et al., 2003). Therefore, researchers and development agencies have attempted to improve the sanitary standards of the colonies, promoting the refinement or identification of diagnostic methods as a way to improve health monitoring (Schoondermark-Van de Ven et al., 2006).

In this study, the positive sera showed a significant increase in the absorbance values consistent with an increase in the antigen concentration used, without significant alterations in the values for the negative serum. The concentration of $2 \mu \mathrm{g} / \mathrm{mL}$ was chosen for the test because it allowed lower antigen consumption while ensuring good discrimination between positive and negative sera, thereby improving the economy of the test. The use of higher concentrations would imply higher antigen consumption and an increase in the dilution of the control sera and consequently of the test sera, which could imply lower OD values and an increase in the number of false negatives.

The strong control serum response of $M$. arthritidis in the mixed test, even when the $M$. pulmonis antigen ratio was higher, may represent the cross-reaction described by Minion et al. (1984). However, the proportion of 50\% (1:1) was chosen to avoid favoring any of the antigens.

The mixed test showed lower ODs than the specific tests because of the lower amounts of antigens specific for both species tested. Thus, the dilution of $1 / 400$, recommended in the literature (Campos et al., 2000) and considered suitable for the antigens in the standardization, cannot be applied in this work. Therefore, the 1/300 dilution exhibited better discrimination between positive and negative sera in the ELISA-mix, and was selected for the test, allowing detection of small amounts of antibodies in the samples (Davidson et al., 1994).

The 1:15000 dilution of the conjugate could have been recommended for the ELISA-Ma test, which showed high absorbance values even at this dilution, but not for the ELISA-Mp and ELISA-mix tests, for which the OD values were much lower (0.284 for M. pulmonis and 0.209 and 0.352 for the mixed test). Therefore, a 1:10,000 dilution was chosen, which also maintained the absorbance values of negative sera lower than 0.100 at all serum dilutions.

For rodent mycoplasmas, the cut-off points for detecting positive results in indirect ELISA tests are usually obtained by the multiplication of the OD of the negative control by 2.5 (Davidson et al., 1994; Campos et al., 2000). However, in this work, the maximum OD values obtained in sera from positive animals were 0.461 in the ELISA-Mp and 0.432 in the ELISA-mix, which were considered low relative to those obtained previously (above 1.0) (Campos et al., 2000). This is probably attributable to changes in animal management, improvement in the environmental conditions of the vivariums, and the therapeutic use of antibiotics against various bacteria, including mycoplasma. These factors may interfere with seroconversion (Mähler Convenor et al., 2014), resulting in low OD and making it difficult to apply the cut-off point mentioned above. The use of this method would consequently imply a low number of positives with a greater possibility of false negatives, substantially decreasing the sensitivity and specificity of the test.

The binomial test showed a greater difference in the specific ELISA, probably because the number of samples according to the isolation/PCR was higher in the mixed ELISA than in the specific ELISA, although the latter had a higher number of positive sera. Nevertheless, the 
Kappa correlation $(\mathrm{p}<0.0001)$ showed strong concordance between the tests, indicating good performance of the ELISA-mix.

In this study, the sensitivity of ELISA-mix with reference to isolation(72.00\%) was higher than that shown by the ELISA-Mp (68.00\%), which in turn was higher than that reported by Campos et al. (2000), who first standardized a specific ELISA for M. pulmonis (58.34\%). The highest sensitivity obtained for the mixed ELISA was attributable to the adjuvant effect or to the conjugation as a result of the association of antigens, considering protein-hapten interactions, which provided better efficiency.

Because all samples in the isolation/PCR were positive for M. pulmonis, the positive results found in the ELISA-Ma (44.44\%-36/81) improved the efficiency of the test in detecting undesirable mycoplasmas in colonies of rodents. Several factors should be taken into account when analyzing the results found in the mixed ELISA. The age, lineage, sex, time of infection, and origin of the animals may interfere with the intensity of the infection and immune response to mycoplasma (Delgado \& Timenetsky, 2001). This explains some results found in this study, namely, the $20 \%$ negative results in ELISA-Mp that were positive in isolation/PCR.

Among the 81 tested samples, 15 were from animals of SPF vivariums, kept in closed boxes and under controlled sanitary conditions. All samples were negative in the ELISA-mix as well as in the specific ELISAs; these samples were also negative in detection by isolation and/or PCR. This result supports reports about the environmental conditions of vivariums and animal sanitary conditions for the prevention of M. pulmonis infection and the eradication of the microorganism (Pritchett-Corning et al., 2009).

Laboratories around the world use the recommendations of the Federation of Laboratory Animal Science Associations (FELASA) for routine monitoring of colonies. However, FELASA (Mähler Convenor et al., 2014) currently takes into account only M. pulmonis infections, since these recommendations are primarily targeted at laboratories located in Europe and the United States, where the occurrence of M. arthritidis is rare (Washburn et al., 1995). In developing countries such as Brazil, the occurrence of $M$. pulmonis is frequent and that of M. arthritidis is relatively poor; thus, continuous monitoring for these microorganisms is still necessary.

Despite the existence of kits for the detection of rodent mycoplasmas, the ELISA technique has been more intensively studied and adapted with the aim of improving it further (Asano et al., 2014).

Rodent monitoring kits that use antigens of diverse pathogens, including M. pulmonis, are available in the market. However, these tests are expensive and obtaining them is difficult for most Brazilian vivariums.

Higher sensitivity and specificity values have been reported in the development of ELISA tests. However, these studies use sonicated antigens (Campos et al., 2009) or isolated proteins (Asano et al., 2014), and their sensitivity and specificity rates tend to be higher than those of the total antigen test. Nonetheless, the monitoring of mycoplasmosis in rodent colonies is performed with limited resources, and the development of a simpler diagnostic technique may help solve this problem by offering an effective and low-cost test.

This study proposes, for the first time, an alternative to the conventional ELISA test, allowing simultaneous detection of two species of mycoplasma. This test can contribute significantly to monitoring the health conditions of laboratory animals and minimizing the damage caused by mycoplasma infection in these animals and in cell cultures used for scientific research.

\section{References}

Amstislavsky, S. Y., Igonina, T. N., Rozhkova, I. N., Brusentsev, E. Y., Rogovaya, A. A., Ragaeva, D. S., Naprimerov, V. A., Litvinova, E. A., Plyusnina, I. F., \& Markel, A. L. (2013). Rederivation by embryo transfer in strains of laboratory mice and rats. Russian Journal of Genetics: Applied Research, 3(4), 305-315. http://dx.doi.org/10.1134/ $\underline{\mathbf{S} 2079059713040023 .}$

Asano, A., Torigoe, D., Sasaki, N., \& Agui, T. (2014). Development of an ELISA using a recombinant p46-like lipoprotein for diagnosis of mycoplasma pulmonis infection in rodents. The Journal of Veterinary Medical Science, 76(2), 151-157. http://dx.doi.org/10.1292/jvms.13-0308. PMid:24065083.

Ayres, M., Ayres Júnior, M., Ayres, D. L., \& Santos, A. S. (2007). BioEstat 5.0: aplicações estatísticas nas áreas das ciências biológicas e médicas. Belém: MCT, IDSM, CNPq., 364.

Barreto, M. L., Nascimento, E. R., Campos, C. A. M., Nascimento, M. G. F., Lignon, G. B., Lira, M. L. F., \& Silva, R. G. (2002). Detection of Mycoplasma pulmonis in laboratory rats. Brazilian Journal of Microbiology, 33(3), 260264. http://dx.doi.org/10.1590/S1517-83822002000300015. 
Barreto, M. L., Nascimento, E. R., Presgrave, R., Campos, C. A. M., Nascimento, M. G. F., \& Lignon, G. B. (2003). Diagnóstico patológico da micoplasmose respiratória murina. Acta Scientiae Veterinariae, 12, 53-56.

Campos, A. C., Teles, J. A. A., Azevedo, E. O., Nascimento, E. R., Oliveira, M. M. M., Nascimento, S. A., \& Castro, R. S. (2009). ELISA protein G for the diagnosis of contagious agalactia in small ruminants. Small Ruminant Research, 84(1-3), 70-75. http://dx.doi.org/10.1016/j.smallrumres.2009.06.006.

Campos, C. A. M., Nascimento, E. R., Barreto, M. L., Nascimento, M. G. F., \& Verícimo, M. A. (2000). ELISA para o Diagnóstico das Infecções por Mycoplasma pulmonis e Mycoplasma artbritidis em Rattus norvegicus de Biotério. Revista Brasileira de Medicina Veterinária, 22(5), 207-210.

Davidson, M. K., Davis, J. K., Gambill, G. P., Cassel, G. H., \& Lindsey, J. R. (1994). Mycoplasmas of laboratory rodents. In: H. W. Whitford, R. F. Rosenbusch \& L. H. Lauerman. Mycoplasmosis in animals: laboratory diagnosis (pp. 39-50). Ames, Iowa: Iowa State University Press.

Delgado, M. O., \& Timenetsky, J. (2001). Immunoblot profiles of sera from laboratory rats naturally infected with Mycoplasma pulmonis and technicians exposed to infected animals. Brazilian Journal of Microbiology, 32(4), 301-304. http://dx.doi.org/10.1590/S1517-83822001000400009.

Dobbs, N. A., Odeh, A. N., Sun, X., \& Simecka, J. W. (2009). The multifaceted role of T cell-mediated immunity in pathogenesis and resistance to mycoplasma respiratory disease. Current Trends in Immunology, 10, 1-19. PMid:21743780.

Drexler, H. G., \& Uphoff, C. C. (2002). Mycoplasma contamination of cell cultures: incidence, sources, effects, detection, elimination, prevention. Cytotechnology, 39(2), 75-90. http://dx.doi.org/10.1023/A:1022913015916. PMid:19003295.

GV-SOLAS Working Group on Hygiene. (1999). Implications of infectious agents on results of animal experiments. Laboratory Animals, 33 (Suppl. 1), S39-S87. PMID: 10761184.

Horowitz, S. A., \& Cassell, G. H. (1978). Detection of antibodies to Mycoplasma pulmonis by an enzyme-linked immunosorbent assay. Infection and Immunity, 22(1), 161-170. PMid:365742.

Kohn, D. F., \& Barthold, S. W. (1984). Biology and diseases of rats. In: J. G. Fox, B. J. Cohen \& F. M. Loew. Laboratory animal medicine (pp. 91-122). USA: Academic Press Inc.

Luo, W., Yu, H., Cao, Z., Schoeb, T. R., Marron, M., \& Dybvig, K. (2008). Association of Mycoplasma arthritidis mitogen with lethal toxicity but not with arthritis in mice. Infection and Immunity, 76(11), 4989-4998. http:// dx.doi.org/10.1128/IAl.00667-08. PMid:18779340.

Mähler Convenor, M., Berard, M., Feinstein, R., Gallagher, A., Illgen-Wilcke, B., Pritchett-Corning, K., \& Raspa, M. (2014). FELASA working group on revision of guidelines for health monitoring of rodents and rabbits). FELASA recommendations for the health monitoring of mouse, rat, hamster, guinea pig and rabbit colonies in breeding and experimental units. Laboratory Animals, 48(3), 178-192. http://dx.doi.org/10.1177/0023677213516312. PMid:24496575.

Mähler, M., \& Köhl, W. (2009). A serological survey to evaluate contemporary prevalence of viral agents and Mycoplasma pulmonis in laboratory mice and rats in western Europe. Laboratory Animals, 38(5), 161-165. http://dx.doi.org/10.1038/laban0509-161. PMid:19384313.

Manjunath, S., Kulkarni, P. G., Nagavelu, K., Samuel, R. J., Srinivasan, S., Ramasamy, N., Hegde, N. R., \& Gudde, R. S. (2015). Sero-prevalence of rodent pathogens in India. PLoS One, 10(7), e0131706. http://dx.doi.org/10.1371/ journal.pone.0131706. PMid:26158453.

Minion, F. C., Brown, M. B., \& Cassell, G. H. (1984). Identification of cross- reactive antigens between Mycoplasma pulmonis and Mycoplasma arthritidis. Infection and Immunity, 43(1), 115-121. PMid:6690399.

Nicolet, J. (1996). Animal mycoplasmosis: a general introduction. Revue scientifique et technique (International Office of Epizootics), 15(4), 1233-1240. PMid:9190015.

Pritchett-Corning, K. R., Cosentino, J., \& Clifford, C. B. (2009). Contemporary prevalence of infectious agents in laboratory mice and rats. Laboratory Animals, 43(2), 165-173. http://dx.doi.org/10.1258/la.2008.008009. PMid:19015179.

Razin, S. (1996). Mycoplasmas In: Baron S. Medical microbiology (4th ed., Vol. 37, 1273 p.). Galveston: University of Texas Medical Branch at Galveston. Retrieved in ano, Mes dia, from http://www.ncbi.nlm.nih.gov/books/ NBK7627/

Santurio, J. M., Leal, A. T., Leal, A. M., Alves, S. H., Lübeck, I., Griebeler, J., \& Copetti, M. V. (2006). Teste de ELISA indireto para o diagnóstico sorológico de pitiose. Pesquisa Veterinária Brasileira, 26(1), 47-50. http://dx.doi. org/10.1590/S0100-736X2006000100010.

Schoondermark-Van de Ven, E. M. E., Philipse-Bergmann, I. M. A., \& Van Der Logt, J. T. M. (2006). Prevalence of naturally occurring viral infections, Mycoplasma pulmonis and Clostridium piliforme in laboratory rodents in Western Europe screened from 2000 to 2003. Laboratory Animals, 40(2), 137-143. http://dx.doi.org/10.125 8/002367706776319114. PMid:16600073.

Souza, J. B., Silva, M. T. O., Nascimento, E. R., Verícimo, M. A., \& Barreto, M. L. (2016). Mycoplasma pulmonis, Agente da micoplasmose respiratória murina: revisão. Archives of Veterinary Science, 21(4), 8-25.

Washburn, L. R., Voelker, L. L., Ehle, L. J., Hirsch, S., Dutenhofer, C., Olson, K., \& Beck, B. (1995). Comparison of Mycoplasma arthritidis strains by enzyme-linked immunosorbent assay, immunoblotting, and DNA restriction analysis. Journal of Clinical Microbiology, 33(9), 2271-2279. PMid:7494014. 